\title{
Postmortem Biopsies of the Lung, Heart, Liver, and Spleen of COVID-19 Patients
}

\author{
Isil Yurdaisik ${ }^{1}$, Ahu Senem Demiroz ${ }^{2}$, Aysim Buge Oz ${ }^{2}$, Mustafa Akker ${ }^{1}$, Ayse Gul \\ Agirman $^{3}$, Suleyman Hilmi Aksoy ${ }^{4}$, and Fuat Nurili ${ }^{5}$ \\ ${ }^{1}$ Affiliation not available \\ ${ }^{2}$ Istanbul University-Cerrahpasa \\ ${ }^{3}$ Istanbul Dr Siyami Ersek Gogus Kalp ve Damar Cerrahisi Egitim ve Arastirma Hastanesi \\ ${ }^{4}$ Hisar Intercontinental Hospital \\ ${ }^{5}$ Memorial Sloan Kettering Cancer Center
}

May 1, 2021

\begin{abstract}
Objective: We aimed to evaluate histopathologic alterations in the lung, heart, liver, and spleen of coronavirus disease 2019 (COVID-19) decedents through postmortem core needle biopsies. Materials and Methods: Patients who died of reverse transcription-polymerase chain reaction-proven COVID-19 were included in this postmortem case series. Postmortem percutaneous ultrasound-guided biopsies using 14- and 16-gauge needles were performed in the lungs, heart, liver, and spleen. Biopsy samples were stained with hematoxylin-eosin and examined under a light microscope. Clinicodemographic characteristics, chest computed tomography (CT) images, and COVID-19-related treatments of the patients were also collected. Results: Seven patients were included in this study. Liver and heart tissue samples were available from all patients, and lung and spleen tissues were available from five and three patients, respectively. Chest CT images predominantly revealed bibasilar ground-glass opacities. Lung biopsies showed diffuse alveolar damage in all biopsy specimens. Heart findings were nonspecific and largely compatible with the underlying disease. Patchy necrosis, steatosis, and mononuclear cellular infiltration were the main findings in the liver biopsies. Splenic histopathological examination showed that splenic necrosis and neutrophil infiltration were the common findings in all patients. Conclusion: Tissue acquisition was complete for the heart and liver and acceptable for lungs. The amount of tissue was sufficient for a proper histopathologic examination. The histopathological findings were generally in accordance with previous autopsy studies. The lung radiological findings were also correlated with the histopathologic findings. We consider that a postmortem biopsy is a feasible alternative for histopathological examinations in COVID-19 decedents.
\end{abstract}

\section{Postmortem Biopsies of the Lung, Heart, Liver, and Spleen of COVID-19 Patients}

\section{Abstract}

Objective: We aimed to evaluate histopathologic alterations in the lung, heart, liver, and spleen of coronavirus disease 2019 (COVID-19) decedents through postmortem core needle biopsies.

Materials and Methods: Patients who died of reverse transcription-polymerase chain reaction-proven COVID-19 were included in this postmortem case series. Postmortem percutaneous ultrasound-guided biopsies using 14- and 16-gauge needles were performed in the lungs, heart, liver, and spleen. Biopsy samples were stained with hematoxylin-eosin and examined under a light microscope. Clinicodemographic characteristics, chest computed tomography (CT) images, and COVID-19-related treatments of the patients were also collected. 
Results: Seven patients were included in this study. Liver and heart tissue samples were available from all patients, and lung and spleen tissues were available from five and three patients, respectively. Chest CT images predominantly revealed bibasilar ground-glass opacities. Lung biopsies showed diffuse alveolar damage in all biopsy specimens. Heart findings were nonspecific and largely compatible with the underlying disease. Patchy necrosis, steatosis, and mononuclear cellular infiltration were the main findings in the liver biopsies. Splenic histopathological examination showed that splenic necrosis and neutrophil infiltration were the common findings in all patients.

Conclusion: Tissue acquisition was complete for the heart and liver and acceptable for lungs. The amount of tissue was sufficient for a proper histopathologic examination. The histopathological findings were generally in accordance with previous autopsy studies. The lung radiological findings were also correlated with the histopathologic findings. We consider that a postmortem biopsy is a feasible alternative for histopathological examinations in COVID-19 decedents.

Keywords: biopsy, COVID-19, heart, histopathologic, liver, lung, postmortem, SARS-CoV-2, spleen

\section{What is already known?}

* The exact pathophysiology of COVID-19, the disease caused by SARS-CoV-2, has yet to be fully elucidated.

* Performing autopsies in COVID-19 decedents is considered safe, as long as the necessary safety procedures are implemented.

* The number of autopsy studies on COVID-19 patients is still not at a desired level.

\section{What this paper adds?}

* This work is the first postmortem biopsy study to examine splenic core needle biopsies.

* The pulmonary radiological findings are correlated with the lung histopathologic examination results.

* A study design comparing postmortem biopsies with autopsy findings in the same patients can certainly determine the role of postmortem biopsies in COVID-19 decedents.

\section{Introduction}

A novel virus called severe acute respiratory syndrome coronavirus-2 (SARS-CoV-2) first appeared in China through rapidly progressing pneumonia cases and then gave rise to a pandemic. At the time of writing this manuscript,coronavirus disease 2019 (COVID-19) has claimed more than 720,000 lives around the world [1]. The pandemic is still ravaging many parts of the world, and fears of a more widespread second wave are growing.

The exact pathophysiology of COVID-19, the disease caused by SARS-CoV-2, has yet to be fully elucidated. According to preliminary studies, the virus enters the cells via ACE2 cell surface receptors $[2,3]$. As these receptors are abundant in lung tissue, the disease affects the lungs more severely than other parts of the body. As in the case of other newly described disease entities, the histopathological examination of affected tissues is of paramount importance to better understand the pathophysiology of COVID-19. However, with the fear of spreading the disease, the autopsy of COVID-19 victims is prohibited or advised against, even in developed countries. This reluctance to perform autopsies translates to the relative scarcity of autopsy studies, which are not commensurate with the commonality of COVID-19. This approach has been criticized by some authors [4,5]. Performing autopsies in COVID-19 decedents is considered safe, as long as the necessary safety procedures are implemented. The risk of contracting COVID-19 while performing autopsy has been shown to be exceedingly small [6]. As a result of the efforts of the scientific community, albeit still insufficient, the number of autopsy studies on COVID-19 patients has slightly increased in recent literature [7-11].

One way to overcome the regulatory barriers against performing autopsy and the fear of contraction is postmortem biopsy. As the operator spends less time performing the procedure and with less exposure to the tissues of the decedent, unlike in autopsy, postmortem biopsies seem to be a reasonable and acceptable 
alternative to the autopsy of COVID-19 patients. However, as in the case of autopsies, postmortem biopsy studies are not sufficient during the COVID-19 pandemic. To the best of our knowledge, only three studies in the literature have reported postmortem biopsy findings in COVID-19 decedents [12-14].

More postmortem biopsy studies are needed to confirm the efficiency of the procedure in terms of acquiring a sufficient amount of affected tissue. As far as we know, none of the postmortem studies have yet taken spleen samples from COVID-19 decedents. Thus, we aimed to perform a case series in which postmortem core needle biopsies of the lung, liver, heart, and spleen of COVID-19 decedents were conducted. We also evaluated the correlation of pulmonary radiological findings with postmortem pathologic findings.

\section{Materials and Methods}

Study patients and design

Seven patients who died from COVID-19 were included in this postmortem study. All patients had confirmed SARS-CoV-2 infection through the reverse transcription-polymerase chain reaction (RT-PCR) test applied to samples obtained with nasopharyngeal and oropharyngeal swabs. The RT-PCR tests (Bio-Rad, Life Science Research, Hercules, CA) were performed by trained technicians according to the manufacturer's guidelines. All patients with suggestive symptoms of COVID-19 were admitted to the dedicated COVID-19 ward of our pandemic hospital. The local ethics committee approved the study protocol (2017-KAEK-120/2/2020.G039). The written informed consent forms were signed by the legal guardians of all included patients before the postmortem biopsy.

Postmortem core needle biopsy

One of the authors (IY) performed ultrasound-guided multiple percutaneous biopsies of the lungs, kidneys, heart, and spleen using 14- and 16-gauge biopsy needles. The operator used personal protective equipment while performing the biopsies.

Preparation and assessment of biopsy samples

The tissue samples were fixed in $10 \%$ buffered formalin for $48 \mathrm{~h}$ and processed for routine histopathological examination. The samples were then embedded in paraffin for serial sectioning. Sections $4 \mu \mathrm{m}$ in size were stained with hematoxylin and eosin $(\mathrm{H} \& \mathrm{E})$ and examined under a light microscope by experienced pathologists.

Collection of patient data

The electronic hospital database system and patient charts were reviewed to obtain data regarding history, presenting symptoms and physical findings, length of hospital stay (in the ward and intensive care unit [ICU]), administered treatments, admission laboratory values, and imaging studies for each study patient.

\section{Statistical Analysis}

Descriptive analyses were summarized as the median (range) and percentage as appropriate. All statistical analyses were performed using the SPSS 24 (SPSS Inc., Chicago, IL, USA) statistical software package.

\section{Results}

Laboratory and clinical characteristics of the patients

Seven deceased COVID-19 patients (two females) were included in this postmortem biopsy study. The median age was 62 years (range: 39-93 years). All patients had comorbid chronic medical conditions. Hypertension was the most common comorbidity and was present in all patients, followed by diabetes mellitus in five out of the seven patients. One patient died in the ward, and the remaining patients died in the ICU. As part of the national guideline issued by the Ministry of Health of Turkey, all patients were treated with the following drug protocol: azithromycin + hydroxychloroquine + favipiravir. Depending on the severity of the disease and at the caring physician's discretion, some patients were treated with tocilizumab and/or convalescent plasma donated by COVID-19 survivors. Patients who were connected to a mechanical ventilator in the 
ICU were administered $1 \mathrm{mg} / \mathrm{kg}$ body weight of methylprednisolone. Patients' demographic and clinical characteristics are shown in Table 1 .

Chest computed tomography (CT) findings

Six of the seven patients underwent chest CT scanning. The universal finding in all patients was the presence of ground-glass opacities (GGO), which were usually more prominent in the basilar areas of the lungs. Five patients $(55.5 \%)$ had pleural effusion, and three patients $(33.3 \%)$ had pericardial effusion (one patient had simultaneous pleural and pericardial effusion, and one had neither of them). One notable feature was that all patients had cardiomegaly on the CT images. Given the prevalent history of coronary artery disease and left ventricular hypertrophy among the patients, this latter finding was not surprising. Table 1 presents a summary of the chest CT imaging findings.Figures 1-3 illustrate the lung radiological findings in three patients. Figure 4 shows the progression of the lesions in one patient through the volume rendering technique chest CT images.

Histopathologic findings

Lungs

Lung tissue was available in five out of the seven patients. One patient (Patient 4) showed findings of early acute respiratory distress syndrome (ARDS). This patient had hyaline membranes and edema in the alveoli. In all other patients (Patients 2, 3, 5, and 7), examination of the lung biopsy specimens revealed the organizing phase of ARDS. These patients had remarkable septal thickening and collagen increase. Table 2presents the details of the histopathologic findings of the lung biopsies. Figures $\mathbf{5}$ and $\mathbf{6}$ illustrate the epithelial and/or vascular diffuse alveolar damage, respectively.

Heart

Heart tissue was present in the biopsy samples of all patients. Only one patient had completely normal cardiac histopathological findings (Patient 3). Cardiomyocyte hypertrophy was the most common finding among the other patients. Glycogen increase (Patients 1, 4, and 5) and fibrosis (Patients 2 and 6) were also observed (Table 3 ).

Liver

Liver tissue was present in all biopsy samples. Hepatocyte necrosis was present in all but one patient. Patients 2 and 5 had extensive hepatocyte necrosis, and the other patients $(1,3,4$, and 6$)$ had patchy necrosis. Patients $2,3,4$, and 7 had macrovesicular steatosis. Two patients ( 1 and 3$)$ had neutrophil infiltration in their liver parenchyma, and the other three patients had mononuclear cell infiltration (Patients 2, 5, and 7). The liver histopathologic findings of the patients are presented in Table 3.

Spleen

Splenic tissue was available in only three patients. Examination of all biopsy samples revealed neutrophils in the red pulp and necrosis (Table 3 ).

\section{Discussion}

The notable findings of this case series are as follows: (i) Tissue acquisition through ultrasound-guided postmortem biopsies was acceptable, particularly for the liver and the heart. A sufficient amount of lung tissue was obtained in five out of the seven patients. (ii) The universal radiological finding was the presence of GGO, particularly in the lower lung lobes. The pathologic counterpart of these images was the organizing phase of ARDS. All but one patient had hyaline membranes in their alveoli. (iii) This is the first study to report splenic postmortem biopsy results in COVID-19 patients. The common finding was necrosis and neutrophil infiltration in the red pulp.

Several studies and case reports have been published to understand histopathological changes and acquire possible ultrastructural clues underlying the widespread damage inflicted by SARS-CoV-2. As the lungs 
are the main target of the virus, pulmonary imaging and histopathology have attracted much attention. Three rough stages have been defined for COVID-19 [15]. The earliest phase is SARS-CoV-2 infection, characterized by fever, dyspnea, and other flu-like symptoms. The second stage involves viral pneumonia, which causes pulmonary inflammation and coagulopathy. Some cases progress to ARDS in this stage. The third and last stage is characterized by the relieving of symptoms and pulmonary fibrosis. These stages are not necessarily consecutive and can coexist in the same patient.

Pulmonary findings are histopathologically classified into three patterns [16-18]. The most common and earliest pattern is diffuse alveolar damage (DAD), which shows varying degrees of organization, desquamation, type-2 pneumocyte hyperplasia, and viral cytopathic changes. The second pattern (vascular) involves intra-alveolar fibrin deposition and/or microvascular thrombi. Fibrotic patterns include fibrotic DAD and/or interstitial fibrosis. A meta-analysis [19] evaluating autopsy studies revealed that pulmonary histopathologic examinations showed an epithelial pattern of injury in $85 \%$ of the included patients. When present, mononuclear cells were the predominant cell type infiltrating the lung interstitium. A vascular pattern was present in $59 \%$ of the patients, and a fibrotic DAD pattern was observed in $22 \%$ of the patients. Among the patients, $60 \%$ had more than one pattern concurrently. Our findings were generally in agreement with previous autopsy studies. The most common pulmonary injury pattern among our patients was epithelial DAD. It was present in four out of the five patients ( $80 \%)$, isolated in two patients, and alongside a vascular DAD pattern in the other two patients. Interstitial inflammation was noted in three patients (50\%) and was mononuclear in all cases. One patient had a concomitant fibrotic and vascular pattern.

Only a few studies to date have reported postmortem biopsy findings in COVID-19 decedents [12-14]. In these studies, 18 COVID-19 decedents were examined through postmortem biopsies. One study [13] evaluated only lung tissue, and two $[12,14]$ studies also examined liver and heart tissues, in addition to lung tissue. Beigmohammadi et al. [12] performed postmortem biopsies with ultrasound guidance, whereas Tian et al. [21] performed blind biopsies based on reference points. Flickweert et al. [13] used ultrasound or CT guidance to perform postmortem biopsies. In these studies, the authors obtained sufficient lung tissue for histopathological examination. Conversely, sufficient lung tissue was not obtained from the two patients in the present study.

Similar to our study, Flikweert et al. and Tian et al. [13, 14] also included chest radiological findings in their reports. Regarding pulmonary histopathologic findings, diffuse alveolar damage was the predominant finding in all three studies.

Myocardial injury is prevalent in COVID-19 patients hospitalized in the ICU [20-22]. In autopsy studies, no specific pathological finding associated with COVID-19 was found in more than half of the patients. Most of the cardiac histopathological findings could be explained by the underlying cardiac disease of the patients, such as coronary artery disease and heart failure $[23,24]$. In the other half, mild interstitial mononuclear cellular infiltration, lymphocytic myocarditis, and myocardial edema were reported [19, 25, 26]. One remarkable aspect was that pericardial effusion was rare. Postmortem biopsy studies have reported nonspecific histopathological findings that are mostly compatible with the underlying cardiac disease of the patients $[12,14]$. In contrast to autopsy and postmortem biopsy studies, pericardial effusion was frequent in our series. Four out of the six patients $(66.6 \%)$ had varying degrees of pericardial effusion. However, no specific COVID-19-associated cardiac histopathologic findings were observed in any of the examined specimens. The observed changes were in accordance with the underlying cardiac diseases of the decedents.

Autopsy studies performed on patients who died of COVID-19 showed mild steatosis, patchy hepatic necrosis, and mild sinusoidal dilation in the vast majority of patients $[23,27]$. In their postmortem series, Beigmohammadi et al. [12] reported sinusoidal dilation, microvesicular and macrovesicular steatosis, and mild portal inflammation. Tian et al. [14] reported sinusoidal dilation and patchy hepatocyte necrosis. Our results showed patchy hepatocyte necrosis, mononuclear and/or neutrophil infiltration, and macrovesicular steatosis in the liver biopsy samples.

Autopsy studies have shown lymphocyte reduction and focal necrosis, infarction, and hemorrhage in the 
spleen [19, 28]. None of the available postmortem studies have obtained splenic biopsies [12, 14]. In our series, splenic tissue was available in three patients. Splenic tissue was not present in the four biopsy samples. All patients had focal necrosis and neutrophil infiltration in the red pulp.

Histopathologic changes in the liver, lung, heart, and spleen in the postmortem biopsy samples were generally similar to those obtained through autopsy. The tissue acquisition rates were quite high: $100 \%$ for liver, $88.8 \%$ for lung, and $88.8 \%$ for heart. Thus, we believe that postmortem biopsies can provide comparably good histopathological results compared with autopsy studies. Furthermore, in postmortem studies, pulmonary histopathologic findings were concordant with radiological images.

This study has several limitations. First, although our sample was not smaller than that of other postmortem biopsy studies, examining more cases can yield more generalizable results. Second, we did not use immunohistochemical staining. Nevertheless, H\&E staining was largely sufficient for the purposes of the study. Third, we did not examine the presence of SARS-CoV-2 in the biopsied tissues. These data, along with the ACE2 expression level, can shed more light on the pathophysiological changes seen in COVID-19. Lastly, as organ involvement could be patchy and as there was no chance of seeing the organs macroscopically, as in autopsy, postmortem biopsy studies have inherently more limited tissue availability than autopsy studies. This might have affected our results to some extent.

In conclusion, this study performed a postmortem biopsy series on COVID-19 decedents by sampling lung, heart, liver, and spleen tissues. This work is the first postmortem biopsy study to examine splenic core needle biopsies. An adequate amount of tissue for histopathologic examination was obtained in most biopsies. When adequate tissue was sampled, the results were generally consistent with previous autopsy studies. The pulmonary radiological findings were correlated with the lung histopathologic examination results. A study design comparing postmortem biopsies with autopsy findings in the same patients can certainly determine the role of postmortem biopsies in COVID-19 decedents.

Acknowledgments: N/A

Conflict of Interest: The authors declare no conflicts of interest.

Financial Disclosure: The authors declare that this study did not receive financial support.

\section{References}

1. https://coronavirus.jhu.edu/map.html, accessed 08.08.2020.

2. Bourgonje AR, Abdulle AE, Timens W, Hillebrands JL, Navis GJ, Gordijn SJ, et al. Angiotensinconverting enzyme 2 (ACE2), SARS-CoV-2 and the pathophysiology of coronavirus disease 2019 (COVID-19). J Pathol. 2020; 251:228-248.

3. Li G, He X, Zhang L, Ran Q, Wang J, Xiong A, et al. Assessing ACE2 expression patterns in lung tissues in the pathogenesis of COVID-19. J Autoimmun. 2020; 112:102463.

4. Pomara C, Li Volti G, Cappello F. COVID-19 Deaths: Are We Sure It Is Pneumonia? Please, Autopsy, Autopsy, Autopsy! J Clin Med. 2020; 26;9:1259.

5. Salerno M, Sessa F, Piscopo A, Montana A, Torrisi M, Patanè F, et al. No Autopsies on COVID-19 Deaths: A Missed Opportunity and the Lockdown of Science. J Clin Med. 2020; 14;9:1472.

6. Davis GG, Williamson AK. Risk of Coronavirus Disease 2019 Transmission During Autopsy. Arch Pathol Lab Med. 2020; 1;144:1445a-1445.

7. Bradley BT, Maioli H, Johnston R, Chaudhry I, Fink SL, Xu H, et al. Histopathology and ultrastructural findings of fatal COVID-19 infections in Washington State: a case series. Lancet. 2020 1;396:320-332.

8. Bryce C, Grimes Z, Pujadas E, Ahuja S, Beasley MB, Albrecht R, et al. Pathophysiology of SARS-CoV-2: targeting of endothelial cells renders a complex disease with thrombotic microangiopathy and aberrant immune response. The Mount Sinai COVID-19 autopsy experience. medRxiv 2020:2020.2005.2018.20099960.

9. Carsana L, Sonzogni A, Nasr A, Rossi RS, Pellegrinelli A, Zerbi P, et al. Pulmonary post-mortem findings in a series of COVID-19 cases from northern Italy: a two-centre descriptive study. Lancet 
Infect Dis 2020; 20:1135-1140.

10. Grosse C, Grosse A, Salzer HJF, Dünser MW, Motz R, Langer R. Analysis of cardiopulmonary findings in COVID-19 fatalities: High incidence of pulmonary artery thrombi and acute suppurative bronchopneumonia. Cardiovasc Pathol 2020; 49:107263

11. Vasquez-Bonilla WO, Orozco R, Argueta V, Sierra M, Zambrano LI, Muñoz-Lara F, et al. A review of the main histopathological findings in coronavirus disease 2019. Hum Pathol. 2020; 105:74-83.

12. Beigmohammadi MT, Jahanbin B, Safaei M, Amoozadeh L, Khoshavi M, Mehrtash V, et al. Pathological Findings of Postmortem Biopsies From Lung, Heart, and Liver of 7 Deceased COVID-19 Patients. Int J Surg Pathol 2020 Jun 19:1066896920935195.

13. Flikweert AW, Grootenboers MJJH, Yick DCY, du Mée AWF, van der Meer NJM, Rettig TCD, et al. Late histopathologic characteristics of critically ill COVID-19 patients: Different phenotypes without evidence of invasive aspergillosis, a case series. J Crit Care 2020;59:149-155.

14. Tian S, Xiong Y, Liu H, Niu L, Guo J, Liao M, et al. Pathological study of the 2019 novel coronavirus disease (COVID-19) through postmortem core biopsies. Mod Pathol. 2020; 33:1007-1014.

15. Wu C, Chen X, Cai Y, Xia J, Zhou X, Xu S, et al. Risk Factors Associated With Acute Respiratory Distress Syndrome and Death in Patients With Coronavirus Disease 2019 Pneumonia in Wuhan, China. JAMA Intern Med. 2020; 1;180:934-943.

16. Copin MC, Parmentier E, Duburcq T, Poissy J, Mathieu D. Lille COVID-19 ICU and Anatomopathology Group. Time to consider histologic pattern of lung injury to treat critically ill patients with COVID-19 infection. Intensive Care Med 2020; 46:1124-1126.

17. Magro C, Mulvey JJ, Berlin D, Nuovo G, Salvatore S, et al. Complement associated microvascular injury and thrombosis in the pathogenesis of severe COVID-19 infection: A report of five cases. Transl Res. 2020; 220:1-13.

18. von der Thüsen J, van der Eerden M. Histopathology and genetic susceptibility in COVID-19 pneumonia. Eur J Clin Invest. 2020; 50:e13259.

19. Polak SB, Van Gool IC, Cohen D, von der Thüsen JH, van Paassen J. A systematic review of pathological findings in COVID-19: a pathophysiological timeline and possible mechanisms of disease progression. Mod Pathol. 2020;33:2128-2138.

20. Bavishi C, Bonow RO, Trivedi V, Abbott JD, Messerli FH, Bhatt DL. Special Article - Acute myocardial injury in patients hospitalized with COVID-19 infection: A review. Prog Cardiovasc Dis. 2020; 63:682-689.

21. Bonow RO, Fonarow GC, O'Gara PT, Yancy CW. Association of Coronavirus Disease 2019 (COVID19) With Myocardial Injury and Mortality. JAMA Cardiol 2020; 1;5:751-753.

22. Deng Q, Hu B, Zhang Y, Wang H, Zhou X, Hu W, et al. Suspected myocardial injury in patients with COVID-19: Evidence from front-line clinical observation in Wuhan, China. Int J Cardiol 2020; $15 ; 311: 116-121$.

23. Varga Z, Flammer AJ, Steiger P, Haberecker M, Andermatt R, Zinkernagel AS, Mehra MR, Schuepbach RA, Ruschitzka F, Moch H. Endothelial cell infection and endotheliitis in COVID-19. Lancet. 2020; 395:1417-1418.

24. Zhang H, Zhou P, Wei Y, Yue H, Wang Y, Hu M, et al. Histopathologic Changes and SARS-CoV-2 Immunostaining in the Lung of a Patient With COVID-19. Ann Intern Med. 2020; 5;172:629-632.

25. Bradley BT, Maioli H, Johnston R, Chaudhry I, Fink SL, Xu H, et al. Histopathology and ultrastructural findings of fatal COVID-19 infections in Washington State: a case series. Lancet. 2020; 1;396:320-332.

26. Tavazzi G, Pellegrini C, Maurelli M, Belliato M, Sciutti F, Bottazzi A, et al. Myocardial localization of coronavirus in COVID-19 cardiogenic shock. Eur J Heart Fail. 2020; 22:911-915.

27. Xu Z, Shi L, Wang Y, Zhang J, Huang L, Zhang C,et al. Pathological findings of COVID-19 associated with acute respiratory distress syndrome. Lancet Respir Med. 2020; 8:420-422.

28. Wichmann D. Autopsy Findings and Venous Thromboembolism in Patients With COVID-19. Ann Intern Med. 2020; 15;173:1030.

Tables 
Table 1. Clinical and demographic characteristics and chest CT findings of the study patients

\begin{tabular}{|c|c|c|c|c|c|c|c|c|}
\hline Patient & Sex, age & $\begin{array}{l}\text { Comorbid } \\
\text { conditions }\end{array}$ & $\begin{array}{l}\text { Length of } \\
\text { hospital } \\
\text { stay } \\
\text { (days) }\end{array}$ & $\begin{array}{l}\text { Length of } \\
\text { ICU stay } \\
\text { (days) }\end{array}$ & $\begin{array}{l}\text { Length of } \\
\text { mechani- } \\
\text { cal } \\
\text { ventila- } \\
\text { tion } \\
\text { (days) }\end{array}$ & $\begin{array}{l}\text { Time } \\
\text { between } \\
\text { the last } \\
\text { chest CT } \\
\text { scan and } \\
\text { death } \\
\text { (days) }\end{array}$ & $\begin{array}{l}\text { Chest CT } \\
\text { findings }\end{array}$ & $\begin{array}{l}\text { COVII } \\
19 \\
\text { treatm }\end{array}$ \\
\hline $\begin{array}{l}\text { Patient } \\
1\end{array}$ & $\mathrm{M}, 62$ & $\begin{array}{l}\text { CABG, } \\
\text { CAD, } \\
\text { LVH, } \\
\text { HT }\end{array}$ & 9 & 0 & 0 & - & - & $\mathrm{A}+\mathrm{H}$ \\
\hline $\begin{array}{l}\text { Patient } \\
2\end{array}$ & M, 39 & $\begin{array}{l}\mathrm{DM}, \\
\mathrm{HT} \\
\mathrm{LVH}\end{array}$ & 22 & 4 & 0 & 3 & $\begin{array}{l}\text { GGO } \\
\text { promi- } \\
\text { nent in } \\
\text { RLL, } \\
\text { cardiomegaly }\end{array}$ & $\begin{array}{l}\mathrm{A}+\mathrm{H} \\
+\mathrm{Fa}+ \\
\mathrm{MP}\end{array}$ \\
\hline $\begin{array}{l}\text { Patient } \\
3\end{array}$ & $\mathrm{~F}, 66$ & $\begin{array}{l}\text { CAD, } \\
\text { LVH, } \\
\text { HT }\end{array}$ & 19 & 7 & 7 & 5 & $\begin{array}{l}\text { Bilateral } \\
\text { exten- } \\
\text { sive } \\
\text { GGO, } \\
\text { consoli- } \\
\text { dation } \\
\text { in basal } \\
\text { areas, } \\
\text { car- } \\
\text { diomegaly, } \\
\text { pericar- } \\
\text { dial } \\
\text { effusion }\end{array}$ & $\begin{array}{l}\mathrm{A}+\mathrm{H} \\
+\mathrm{Fa}+ \\
\mathrm{T}+\mathrm{M}] \\
+ \\
\text { plasma }\end{array}$ \\
\hline $\begin{array}{l}\text { Patient } \\
4\end{array}$ & $\mathrm{~F}, 59$ & $\begin{array}{l}\text { CAD, } \\
\text { LVH, } \\
\text { HT, DM }\end{array}$ & 23 & 14 & 19 & 3 & $\begin{array}{l}\text { GGO, } \\
\text { consoli- } \\
\text { dation, } \\
\text { subseg- } \\
\text { mental } \\
\text { atelecta- } \\
\text { sis and } \\
4 \mathrm{~cm} \\
\text { pleural } \\
\text { effusion, } \\
\text { car- } \\
\text { diomegaly, } \\
\text { pericar- } \\
\text { dial } \\
\text { effusion }\end{array}$ & $\begin{array}{l}\mathrm{A}+\mathrm{H} \\
+\mathrm{Fa}+ \\
\mathrm{T}+\mathrm{M} \\
+ \\
\text { plasma }\end{array}$ \\
\hline
\end{tabular}




\begin{tabular}{|c|c|c|c|c|c|c|c|c|}
\hline Patient & Sex, age & $\begin{array}{l}\text { Comorbid } \\
\text { conditions }\end{array}$ & $\begin{array}{l}\text { Length of } \\
\text { hospital } \\
\text { stay } \\
\text { (days) }\end{array}$ & $\begin{array}{l}\text { Length of } \\
\text { ICU stay } \\
\text { (days) }\end{array}$ & $\begin{array}{l}\text { Length of } \\
\text { mechani- } \\
\text { cal } \\
\text { ventila- } \\
\text { tion } \\
\text { (days) }\end{array}$ & $\begin{array}{l}\text { Time } \\
\text { between } \\
\text { the last } \\
\text { chest CT } \\
\text { scan and } \\
\text { death } \\
\text { (days) }\end{array}$ & $\begin{array}{l}\text { Chest CT } \\
\text { findings }\end{array}$ & $\begin{array}{l}\text { COVII } \\
19 \\
\text { treatm }\end{array}$ \\
\hline $\begin{array}{l}\text { Patient } \\
5\end{array}$ & M, 93 & $\begin{array}{l}\text { CAD, } \\
\text { LVH, } \\
\text { HT, DM }\end{array}$ & 1 & 21 & 17 & 5 & $\begin{array}{l}\text { GGO in } \\
\text { RLL, } \\
\text { consoli- } \\
\text { dation } \\
\text { in left } \\
\text { lung, } \\
\text { left di- } \\
\text { aphragm } \\
\text { eleva- } \\
\text { tion, } \\
\text { car- } \\
\text { diomegaly, } \\
\text { pleural } \\
\text { effusion }\end{array}$ & $\begin{array}{l}\mathrm{A}+\mathrm{H} \\
+\mathrm{Fa}+ \\
\mathrm{T}+\mathrm{M}] \\
+ \\
\text { plasma }\end{array}$ \\
\hline $\begin{array}{l}\text { Patient } \\
6\end{array}$ & $\mathrm{M}, 55$ & $\begin{array}{l}\text { DM, } \\
\text { LVH }\end{array}$ & 20 & 5 & 3 & 4 & $\begin{array}{l}\text { Bibasilar } \\
\text { and } \\
\text { RML } \\
\text { GGO, } \\
\text { car- } \\
\text { diomegaly, } \\
\text { pericar- } \\
\text { dial } \\
\text { effusion }\end{array}$ & $\begin{array}{l}\mathrm{A}+\mathrm{H} \\
+\mathrm{Fa}+ \\
\mathrm{MP}\end{array}$ \\
\hline $\begin{array}{l}\text { Patient } \\
7\end{array}$ & M, 75 & $\begin{array}{l}\text { CAD, } \\
\text { DM }\end{array}$ & 19 & 6 & 5 & 3 & $\begin{array}{l}\text { Bibasilar } \\
\text { GGO } \\
\text { more } \\
\text { promi- } \\
\text { nent on } \\
\text { right } \\
\text { side, } \\
\text { pleural } \\
\text { and } \\
\text { pericar- } \\
\text { dial } \\
\text { effusion, } \\
\text { cardiomegaly }\end{array}$ & $\begin{array}{l}\mathrm{A}+\mathrm{H} \\
+\mathrm{Fa}+ \\
\mathrm{MP}\end{array}$ \\
\hline
\end{tabular}

A: Azithromycin, F: female, Fa: favipiravir, M: male, CABG: coronary artery bypass graft, CAD: coronary artery disease, DM: diabetes mellitus, GGO: ground-glass opacities, H: Hydroxychloroquine, HT: hypertension, LVH: left ventricular hypertrophy, MP: methylprednisolone, RLL: right lower lobe, RML: right middle lobe, T: tocilizumab

Table 2 . Pulmonary pathologic findings of patients who died from COVID-19 


\begin{tabular}{|c|c|c|c|c|c|c|c|}
\hline & Patients & Patients & Patients & Patients & Patients & Patients & Patients \\
\hline $\begin{array}{l}\text { Lung } \\
\text { patho- } \\
\text { logic } \\
\text { findings }\end{array}$ & Patient 1 & Patient 2 & Patient 3 & Patient 4 & Patient 5 & Patient 6 & Patient 7 \\
\hline $\begin{array}{l}\text { Interstitial/a } \\
\text { edema }\end{array}$ & $\begin{array}{l}\text { lixeollamg } \\
\text { tissue }\end{array}$ & $\mathrm{NI}$ & Present & NI & NI & $\begin{array}{l}\text { No lung } \\
\text { tissue }\end{array}$ & $\mathrm{NI}$ \\
\hline $\begin{array}{l}\text { Capillary } \\
\text { mi- } \\
\text { crothrombi }\end{array}$ & - & Present & NI & Present & NI & - & NI \\
\hline Desquamatio & & Present & Present & Present & Present & - & Present \\
\hline $\begin{array}{l}\text { Hyaline } \\
\text { membrane } \\
\text { formation }\end{array}$ & - & Present & Present & Present & Present & - & $\mathrm{NI}$ \\
\hline $\begin{array}{l}\text { Hyaline } \\
\text { mem- } \\
\text { brane } \\
\text { organiza- } \\
\text { tion }\end{array}$ & - & NI & $\mathrm{NI}$ & Present & $\mathrm{NI}$ & - & $\mathrm{NI}$ \\
\hline $\begin{array}{l}\text { Type II } \\
\text { pneumo- } \\
\text { cyte } \\
\text { prolifera- } \\
\text { tion }\end{array}$ & - & Present & Present & NI & Present & - & Present \\
\hline $\begin{array}{l}\text { Cytopathic } \\
\text { effect }\end{array}$ & - & Present & Present & NI & NI & - & $\mathrm{NI}$ \\
\hline $\begin{array}{l}\text { Interstitial } \\
\text { cell } \\
\text { increase }\end{array}$ & - & Present & Present & Present & Present & - & Minimal \\
\hline $\begin{array}{l}\text { Septal } \\
\text { collagen } \\
\text { increase }\end{array}$ & - & NI & NI & NI & NI & - & Present \\
\hline $\begin{array}{l}\text { Septal } \\
\text { thicken- } \\
\text { ing }\end{array}$ & - & Present & Present & Present & Present & - & Present \\
\hline $\begin{array}{l}\text { Mononuclear } \\
\text { cell } \\
\text { increase }\end{array}$ & & Minimal & Present & NI & Minimal & - & $\mathrm{NI}$ \\
\hline $\begin{array}{l}\text { Pathologic } \\
\text { diagnosis }\end{array}$ & & $\begin{array}{l}\text { DAD } \\
\text { (Epithelial } \\
\text { and } \\
\text { vascular) }\end{array}$ & $\begin{array}{l}\text { DAD } \\
\text { (Epithelial) }\end{array}$ & $\begin{array}{l}\text { DAD } \\
\text { (Epithelial } \\
\text { and } \\
\text { vascular) }\end{array}$ & $\begin{array}{l}\text { DAD } \\
\text { (Epithelial) }\end{array}$ & - & $\begin{array}{l}\text { DAD } \\
\text { (vascular } \\
\text { and } \\
\text { fibrotic) }\end{array}$ \\
\hline
\end{tabular}

ARDS: acute respiratory distress syndrome, DAD: Diffuse alveolar damage, NI: Not identified

Table 3 . Pathologic findings in the heart, liver, and spleen of deceased COVID-19 patients

\begin{tabular}{lll}
\hline Patient & Heart & Liver \\
\hline $\mathbf{1}$ & Hypertrophy, glycogen increase & Patchy large necrosis areas, parenchymal neutrophil infiltration, \\
$\mathbf{2}$ & Mild fibrosis, hypertrophy & Microthrombi, extensive hepatocyte necrosis, portal and lobular \\
\end{tabular}




\begin{tabular}{lll}
\hline Patient & Heart & Liver \\
\hline $\mathbf{3}$ & Normal histologic findings & Extensive macrovesicular steatosis, mild sinusoidal dilation, bile \\
$\mathbf{4}$ & Lipomatosis, glycogen increase, hypertrophy & Patchy necrosis, macrovesicular steatosis \\
$\mathbf{5}$ & Hypertrophy, glycogen increase & Extensive hepatocyte necrosis, mononuclear and a few neutrophil \\
$\mathbf{6}$ & Fibrosis & Patchy necrosis \\
$\mathbf{7}$ & Hypertrophy & Extensive macrovesicular steatosis, mild mononuclear cell increas \\
\hline
\end{tabular}

\section{FIGURE}

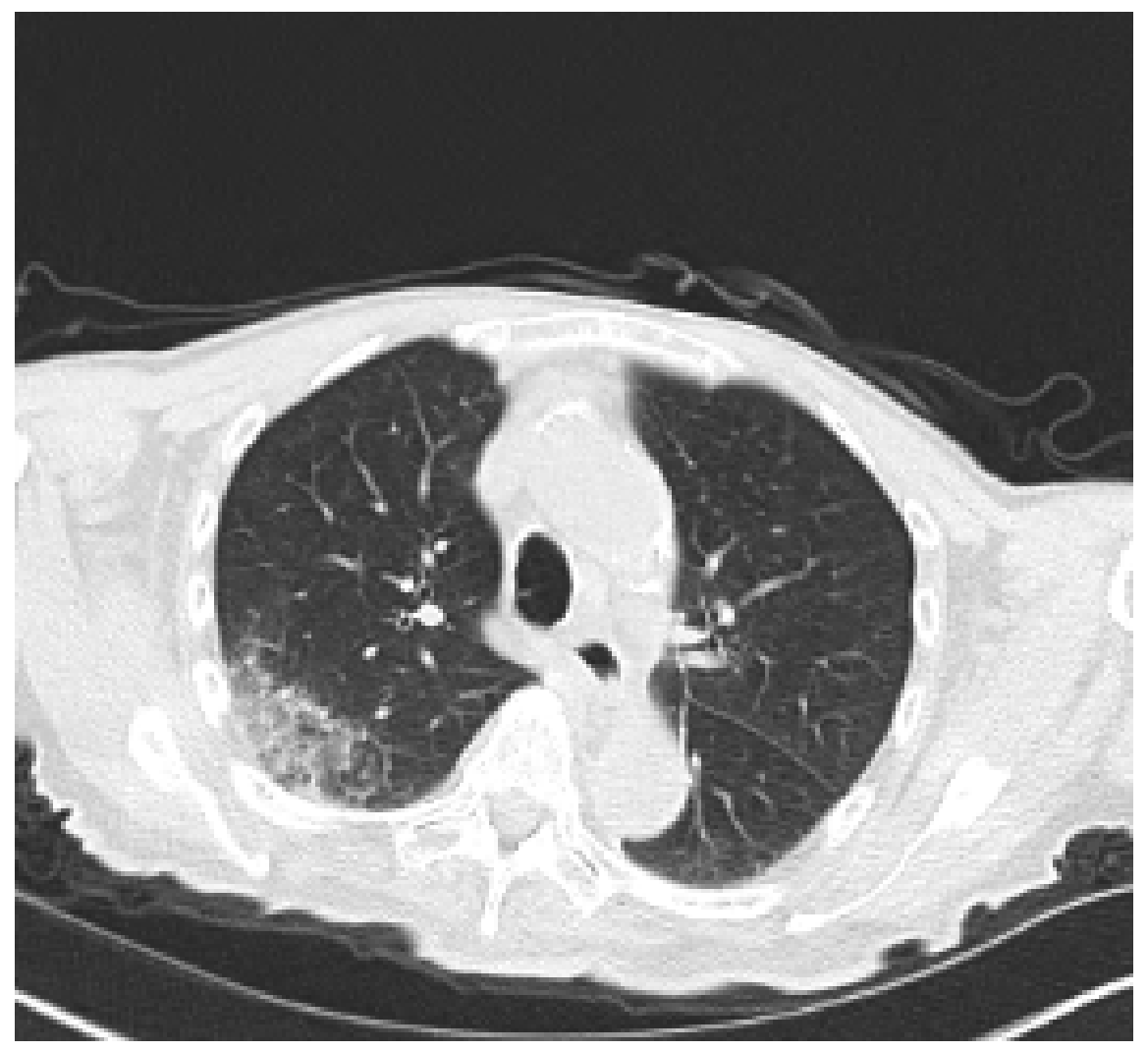

1a . COVID-19 pneumonia 


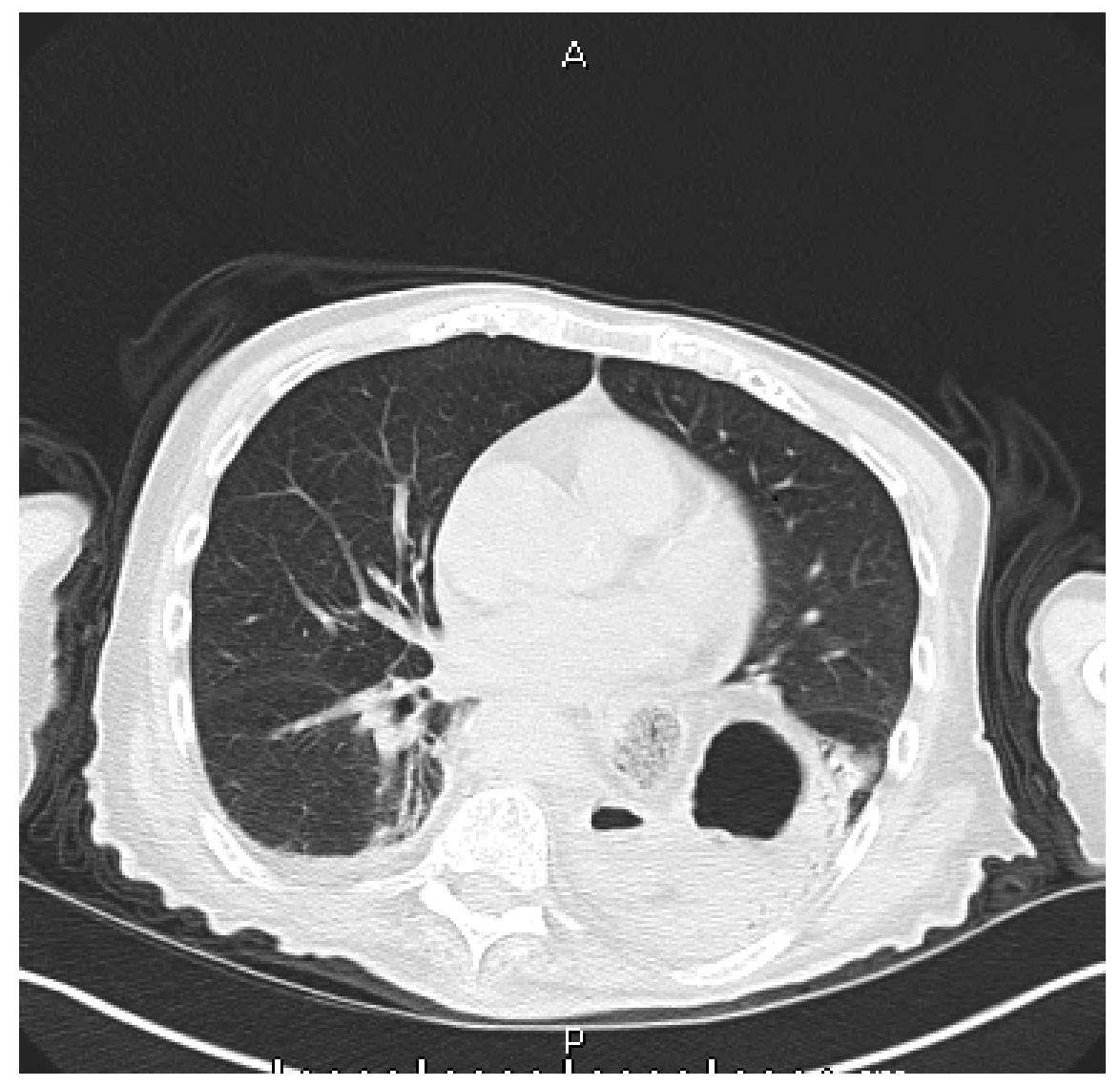

1b. Left-sided hiatal herniation

Figure 1. A 93-year-old male patient who died five days after his chest CT scan. 


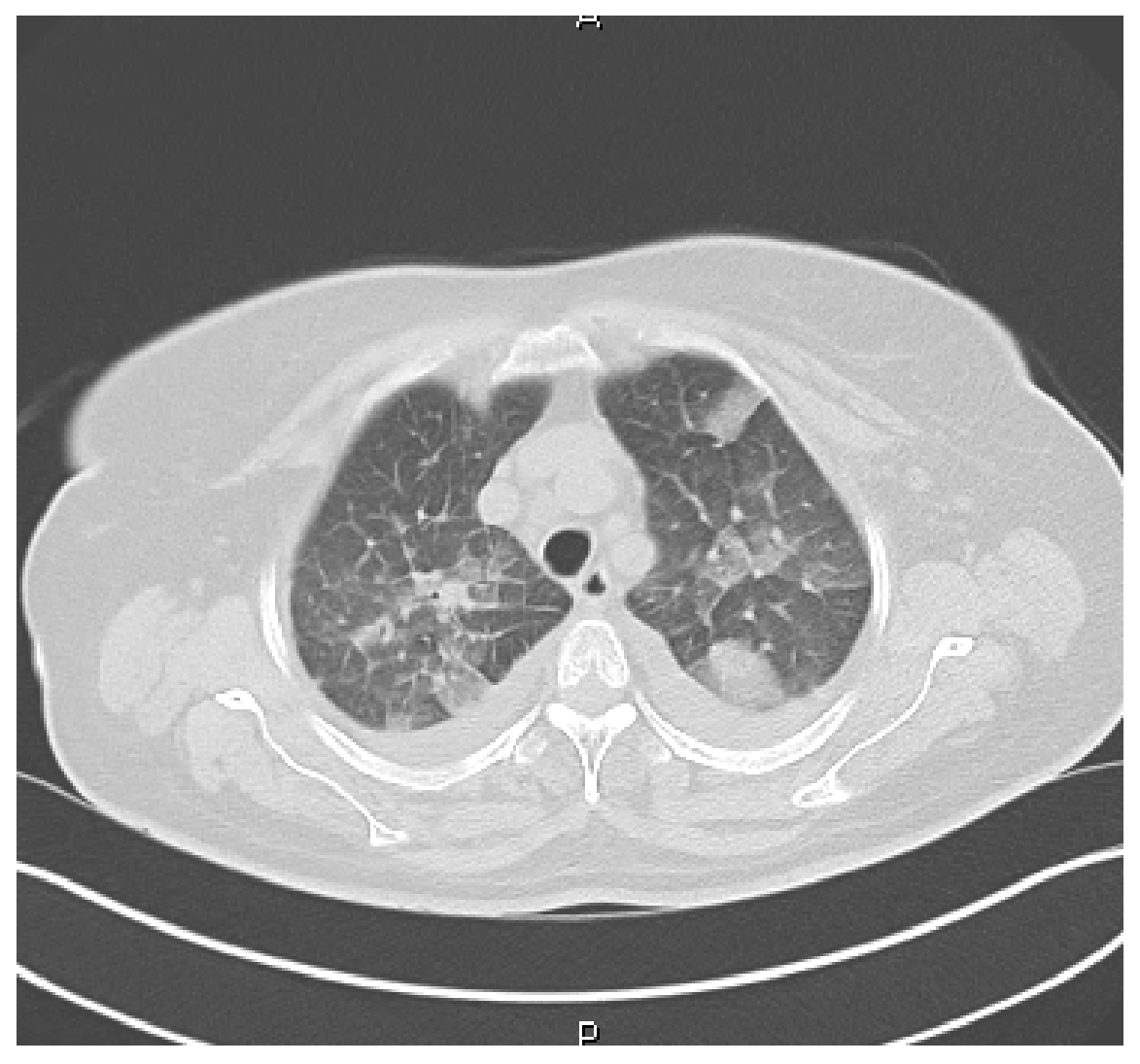




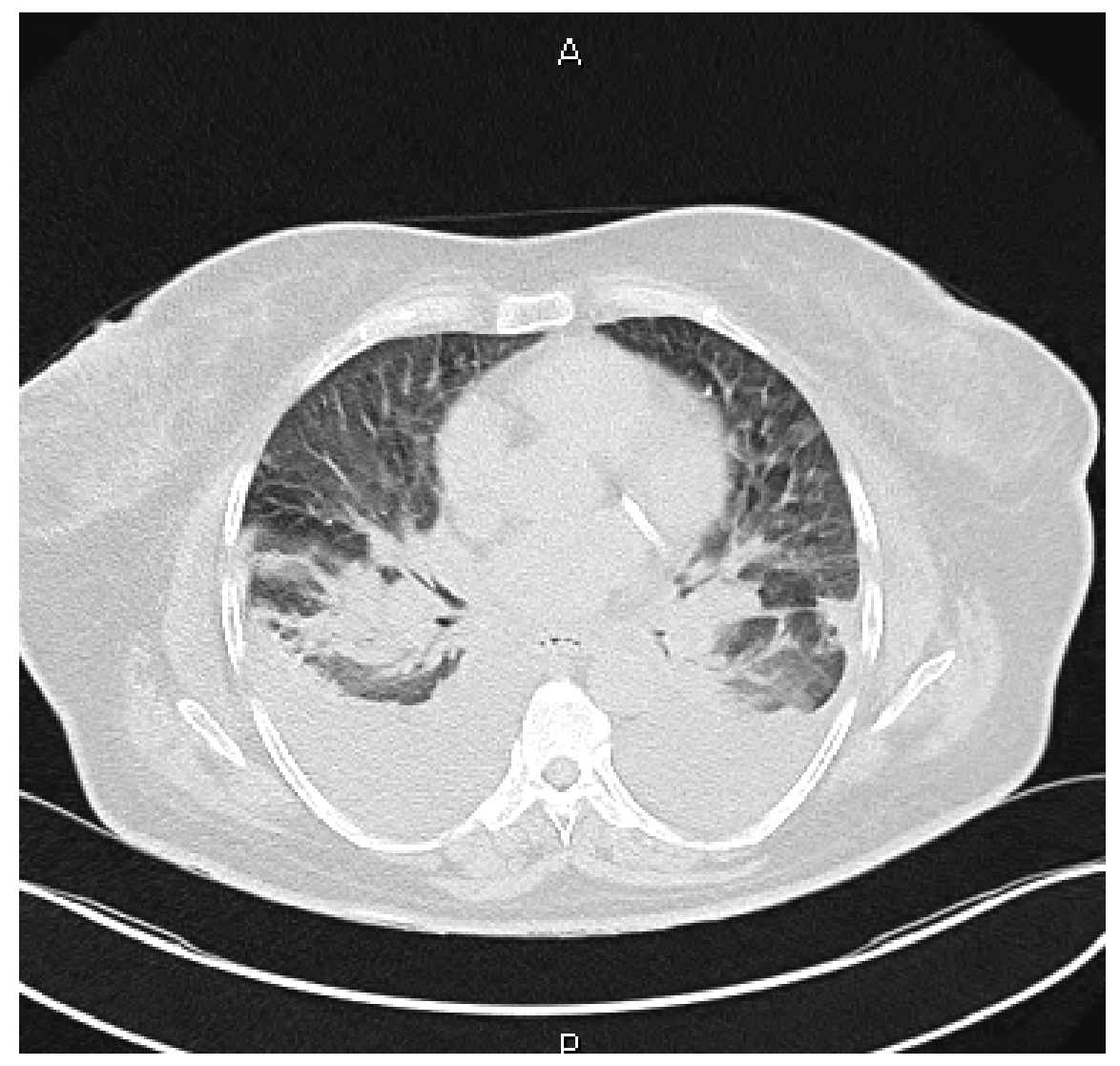

Figure 2. A 59-year-old female patient who died three days after her last chest CT scan Figure 3. A 66-year-old female patient 


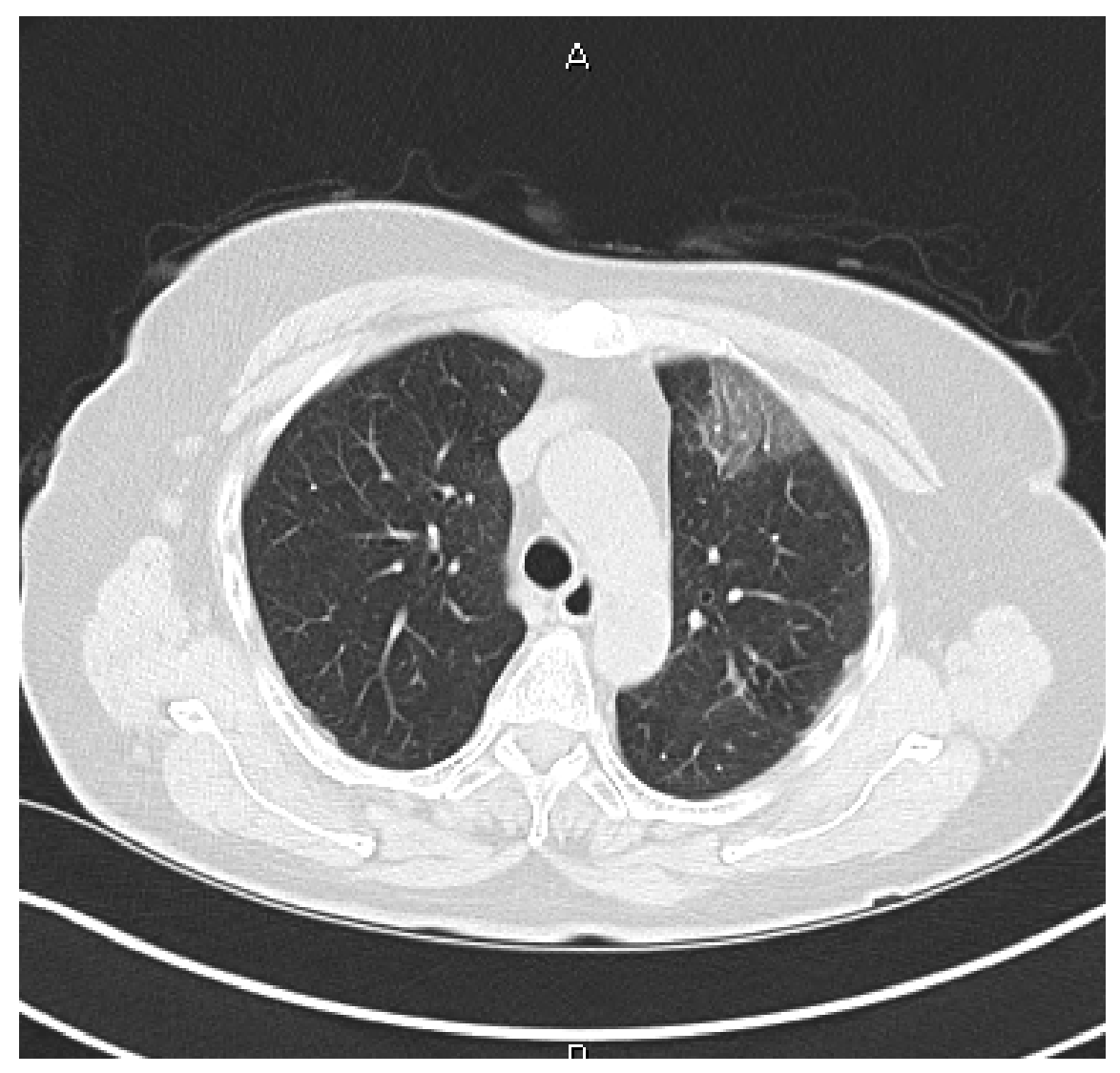

3a. Single lesion in the left upper lobe 


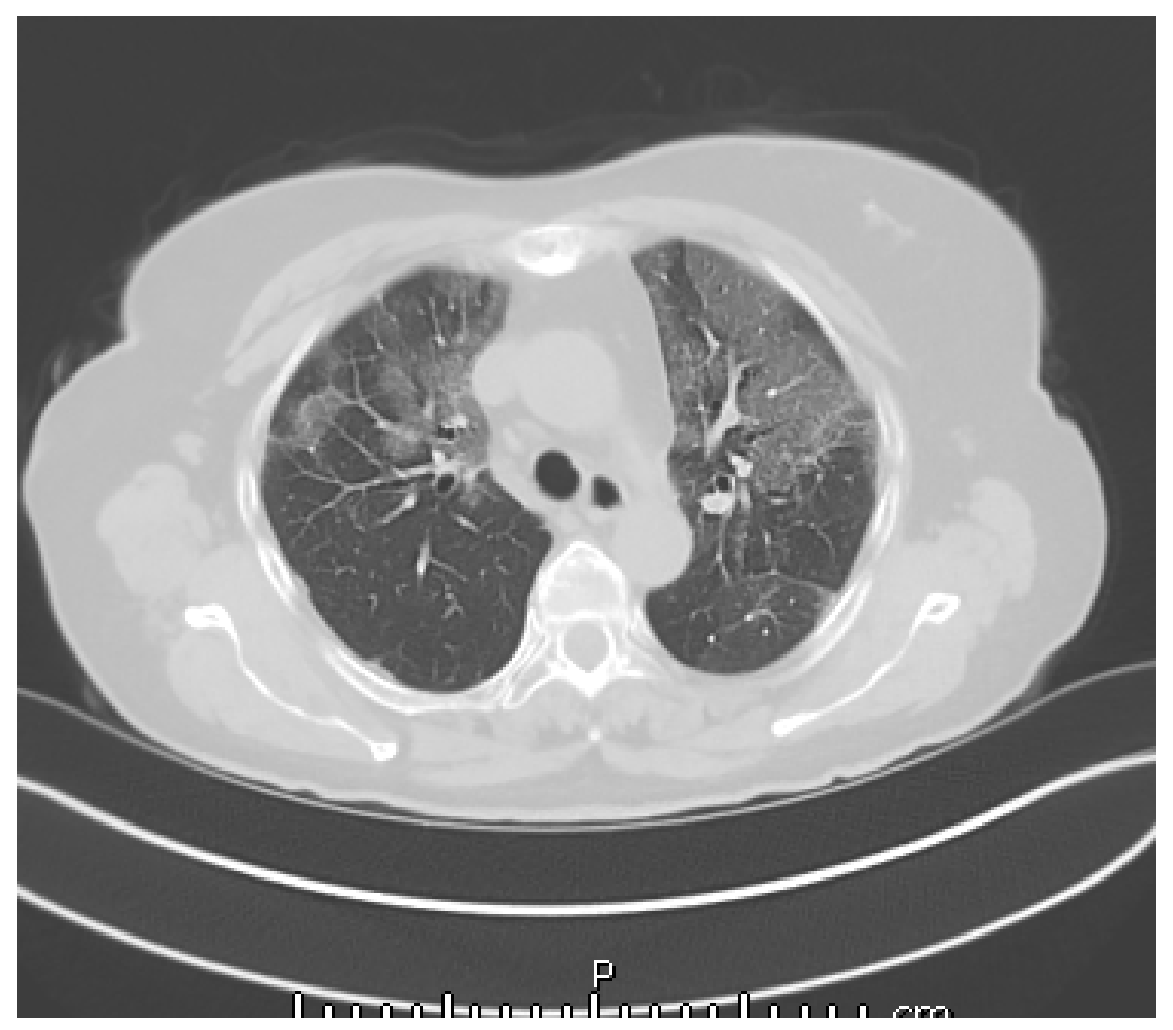

3.2.a. Second chest CT image taken seven days after the first CT; the single lesion in the left upper lobe became bilateral and increased in size.

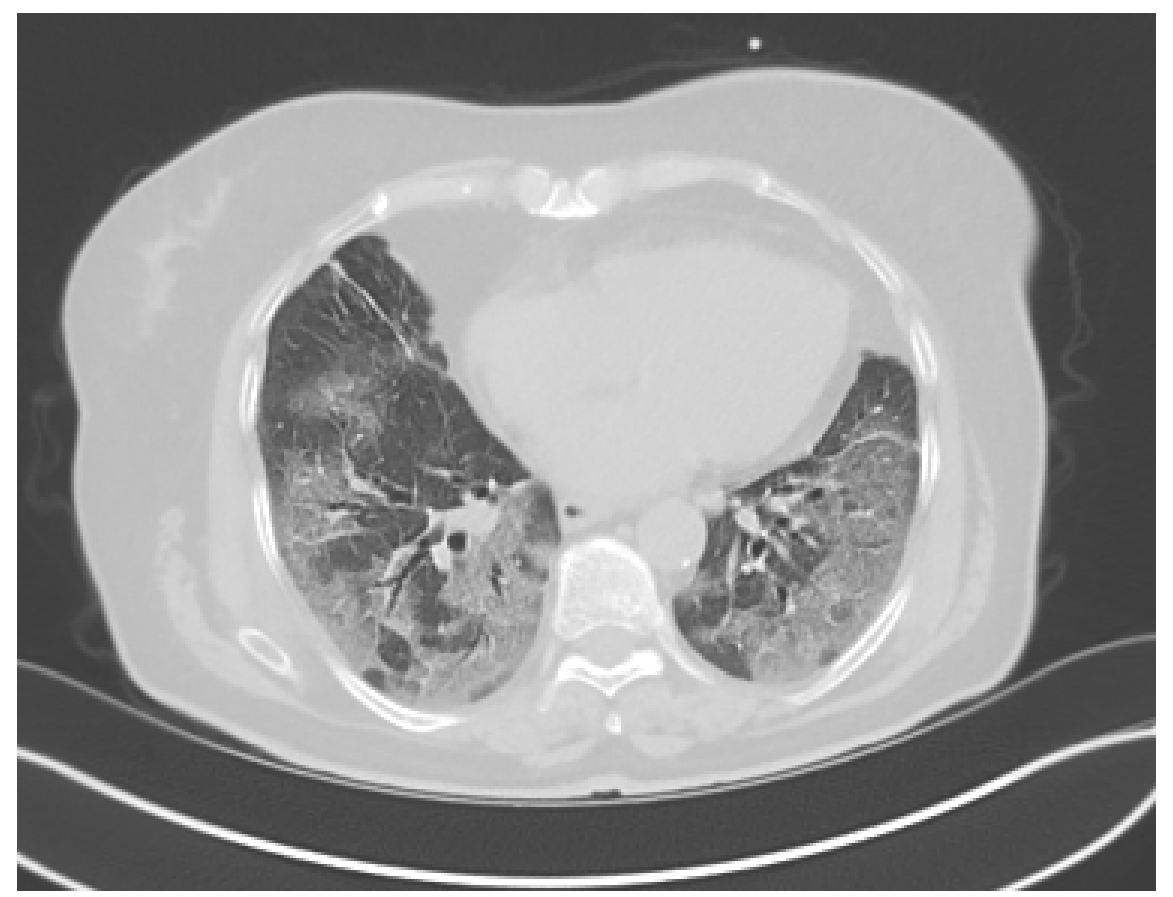


3.2.b. Newly emerged GGO in the lower lobes.

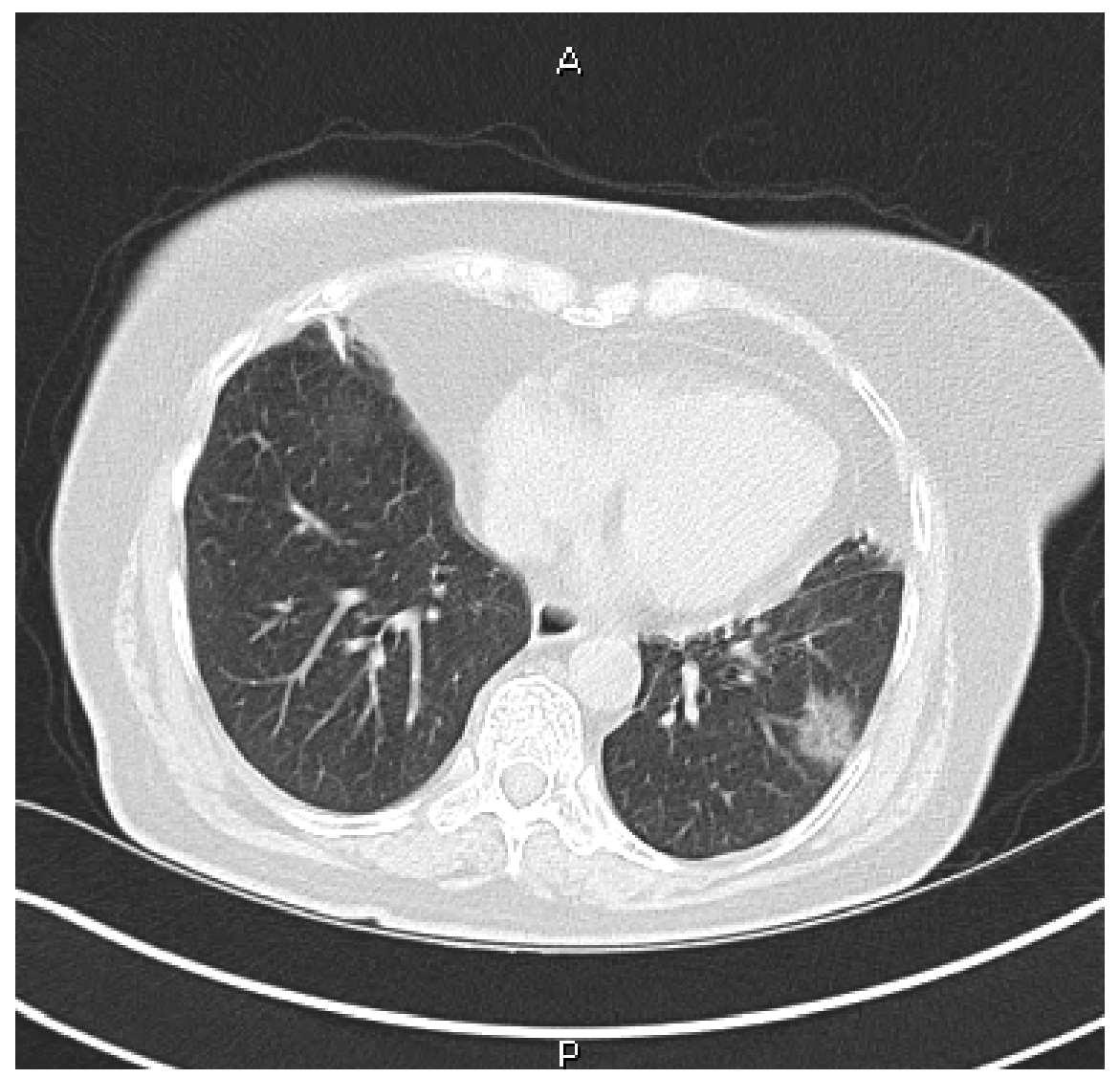

3.3.a. Third chest CT image taken 14 days after the first and seven days after the second CT; increased GGO in the upper lobes 


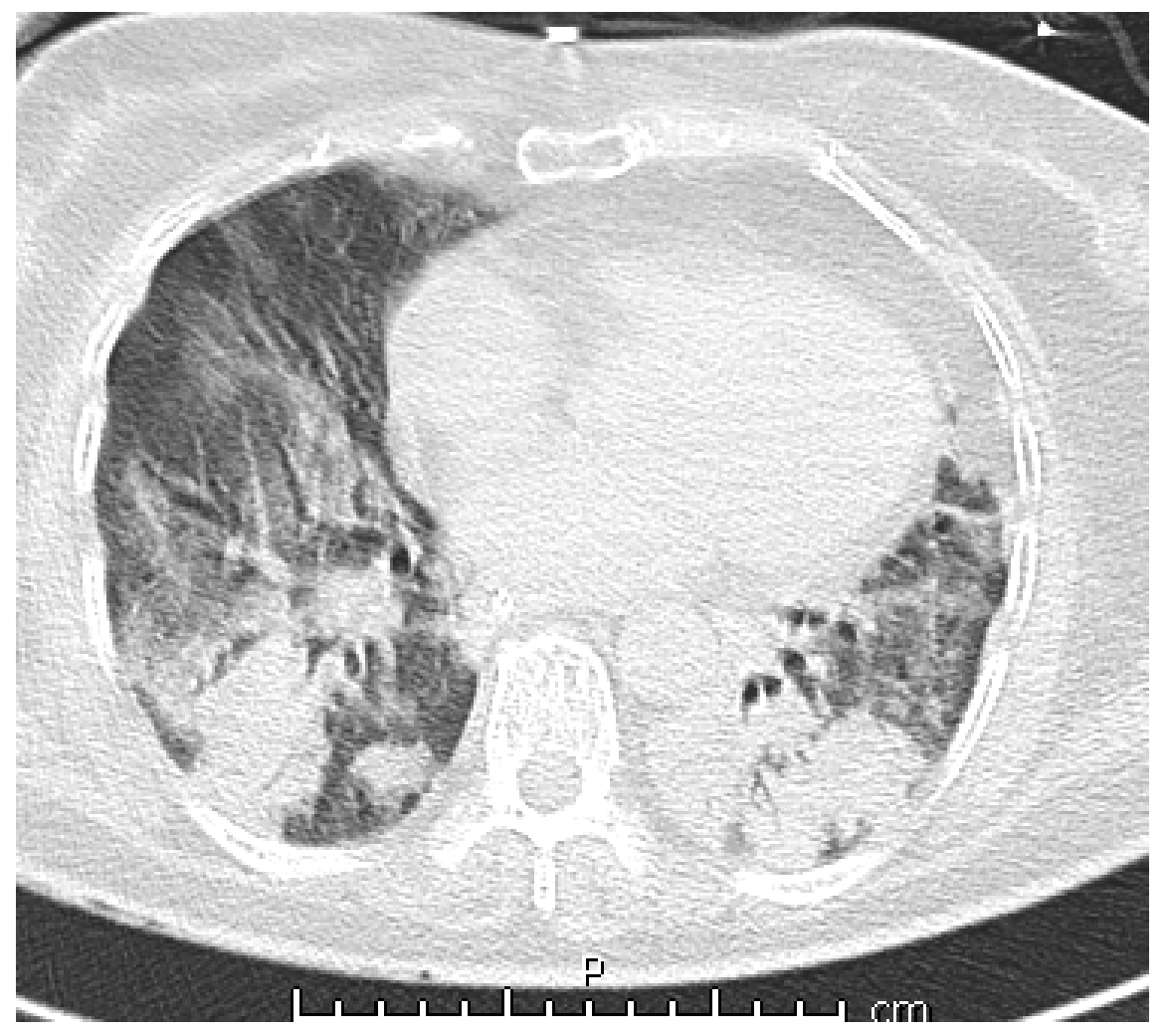

3.3.b. Air bronchograms and GGO accompanying consolidations in the lower lobes

Figure 4. A 75-year-old male patient who died three days after his last CT image. Volume rendering technique chest $\mathrm{CT}$ images 


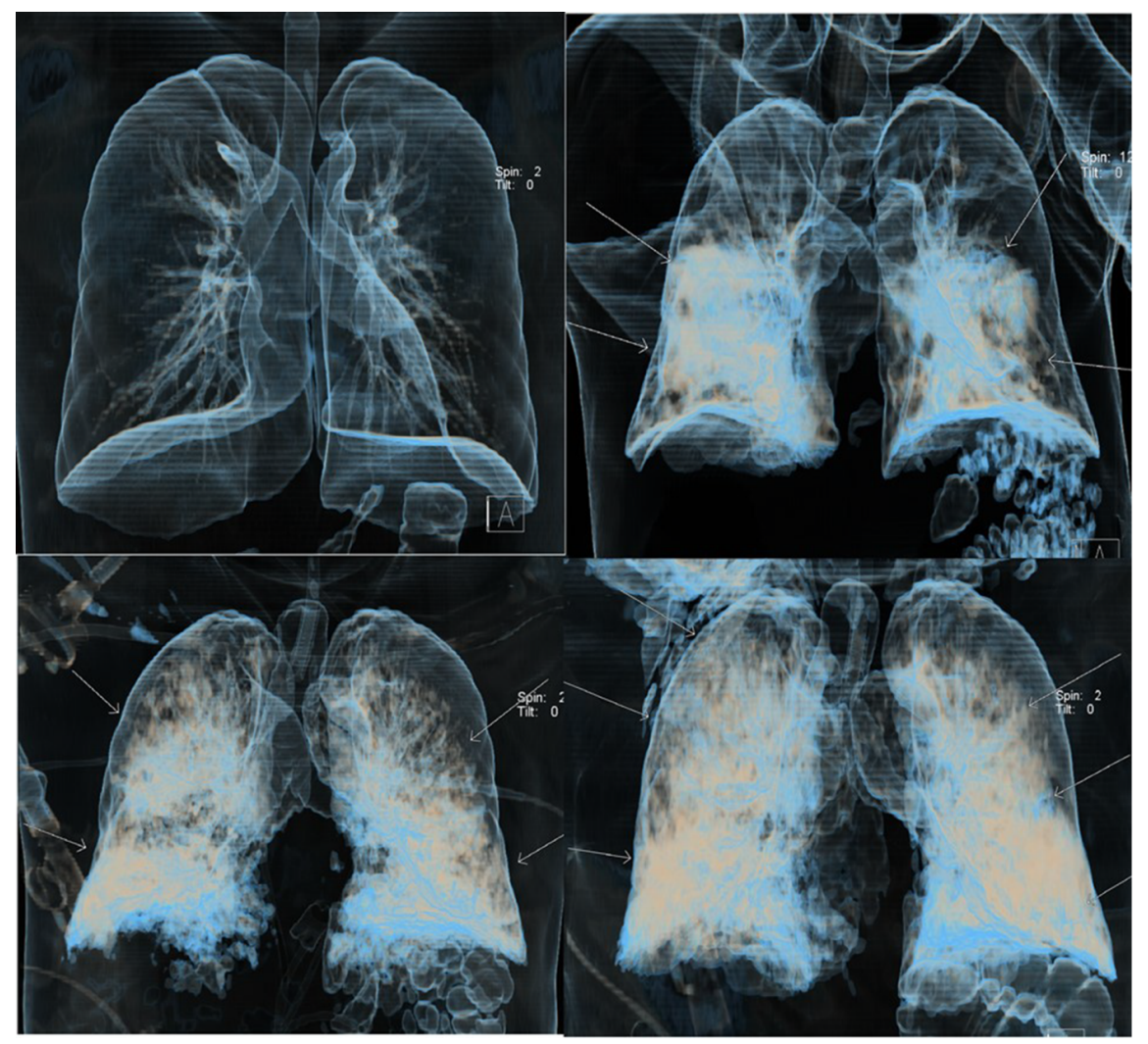

4.a. Normal lung, 4.b-d. Gradual spreading of consolidation from the lower lobes to cover whole lung areas bilaterally. CT images were obtained at 10-day intervals.

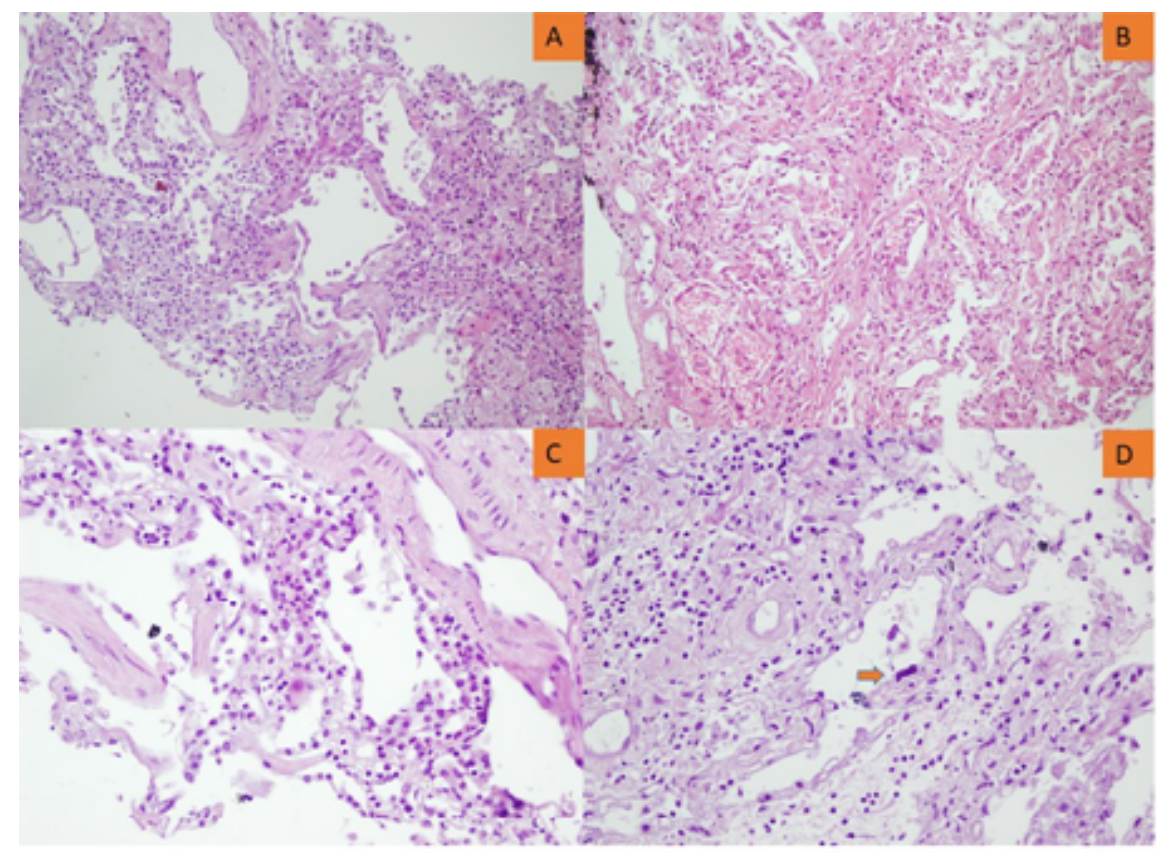


Figure 5 . Lung microscopy showing the early phase of ARDSA. Hyaline membrane (green asterisk, x400). B. Type II pneumocyte proliferation and alveolar desquamation (x400). C.Microthrombi (blue arrows, x200). D. Microthrombi (blue arrows), Type II pneumocyte proliferation, atypical Type II pneumocyte (orange arrow), alveolar desquamation (x400).

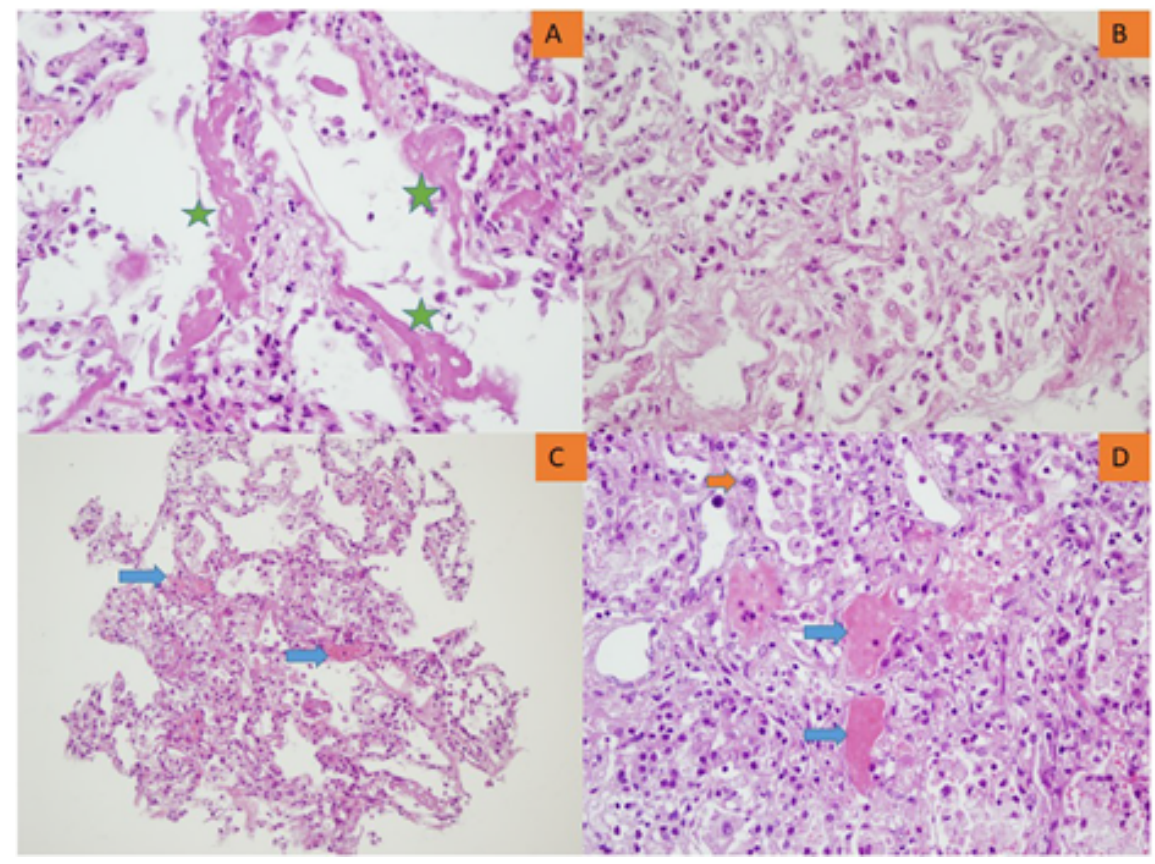

Figure 6 . Lung microscopy showing the late organizing phase of ARDS A. Septal thickening with interstitial cellular increase (x100). B. Septal thickening with interstitial cellular and collagenous increase (x200). C. Interstitial inflammatory cellular infiltration (x400). D. Interstitial thickening with cellular and collagenous increase, atypical type II pneumocyte (orange arrow). 